\title{
Absence of bactericidal activity of orally administered wood creosote on human intestinal bacterial flora
}

\author{
Norio Ogata* and Takanori Miura \\ R \& D Center, Taiko Pharmaceutical Co., Ltd., Kyoto, Japan
}

\begin{abstract}
Wood creosote is a mixture of simple phenolic compounds that has long been used for over a century as an antidiarrheal medicine. While there are many pharmacological studies that explain its antidiarrheal effects, it has long been a matter of controversy whether the antidiarrheal activity of wood creosote is attributable to its putative bactericidal effect on the human intestinal bacterial flora. The objective of our study was to investigate the putative bactericidal effect of wood creosote in the human intestine when given in an ordinary therapeutic dose. To this end, we used an in vitro test to measure the minimal inhibitory concentration of wood creosote for various bacteria from the human gut. In addition, we also quantified the copy numbers of bacterial $16 \mathrm{~S}$ ribosomal DNA in the feces of healthy human participants after administration of a therapeutic dose of wood creosote. We determined the minimal inhibitory concentration of wood creosote to be $>128 \mu \mathrm{g} / \mathrm{ml}$, a level far greater than that of commonly used antibacterial agents. Copy numbers of bacterial $16 \mathrm{~S}$ ribosomal DNA in human feces after the administration of a therapeutic dose of wood creosote did not change significantly $(p>0.05)$ from that before dosing. Taken together, we conclude that wood creosote given at an ordinary therapeutic dose has no significant antibacterial effect in the human lower intestine where most of the intestinal bacterial flora resides. Thus, the antidiarrheal properties of wood creosote are not attributable to its effect on the intestinal bacterial flora, but rather to its other effects on the intestine.
\end{abstract}

\section{Introduction}

Wood creosote (WC) is a mixture of phenolic compounds, such as phenol, guaiacol, $p$-cresol, creosol, 4-ethylguaiacol, obtained by the fractional distillation of wood tar [1]. In some countries WC, under the trade name of Seirogan, has long been used as an antidiarrheal medicine [2]. WC and its constituent compounds are known to suppress enterotoxin-induced intestinal fluid secretion via chloride channels [3-5] and to suppress smooth muscle contraction [6,7]. Indeed, one of the major constituents of WC, 4-ethylguaiacol, is known to possess the latter activity [8]. According to the findings of Morino et al. the antimotility effect of WC is attributable to its inhibition of $\mathrm{Ca}^{2+}$ mobilization in cells of the gastrointestinal tract [9]. Ataka et al. suggested from the results of experiments conducted on rats that stressinduced diarrhea might be inhibited by blocking serotonin receptors in the colon [10].

These reported findings could well explain the antidiarrheal effect of WC. However, it has long been a matter of controversy whether the antidiarrheal effect of WC is attributable to its putative antibacterial activity or not. In fact, WC contains well-known aseptic agents, such as, phenol and $p$-cresol [1], which were previously used as antiseptic agents in hospitals. Medicinal WC taken orally at an ordinary therapeutic dose is immediately absorbed from the gastrointestinal tract; a peak blood concentration of its metabolites being $30 \mathrm{~min}$ after administration $[11,12]$. These findings suggest that WC is absorbed from the upper gastrointestinal tract, namely stomach and duodenum [12]. Moreover, these observations further suggest that the concentration of WC in the lower ileum and colon, where most of the intestinal bacterial floras in human reside, is extremely low. Consequently, the potential antibacterial effect of WC would not be discernible in the lower gastrointestinal tract. If this interpretation is the case, the antidiarrheal effect of WC is unrelated to its potential bactericidal activity. The aim of this study was to investigate whether or not WC taken orally at its ordinary therapeutic dose displays antibacterial activity in the human gastrointestinal tract.

\section{Materials and methods}

\section{In vitro bacterial study}

Minimal inhibitory concentration (MIC) of WC (lot TA-03; Taiko Pharmaceutical, Osaka, Japan) on the growth of various human gut isolates (Don Whitley Scientific, Shipley, UK) was tested according to the reported MIC test guidelines [13]. Agar plates containing culture medium suitable for each bacterium were used. WC diluted to several concentrations in distilled water was added in the agar plates just before they solidified. Special care was exercised to make a homogeneous stock solution of WC in water $(2664 \mu \mathrm{g} / \mathrm{ml})$ by vigorous agitation. After spreading bacteria on the surface of each plate at two bacterial densities, the plates were incubated at $35-42^{\circ} \mathrm{C}$ for $24 \mathrm{~h}$ in aerobic or anaerobic conditions appropriate for each bacterium under investigation. Following incubation, the number of colonies on the plate was counted and the MIC determined. MIC was defined as the concentration of WC at which no bacterial colony appeared on the plates.

Correspondence to: Norio Ogata, MD, PhD, R \& D Center, Taiko Pharmaceutical Co., Ltd., 1-2-1 Hikaridai, Seikacho, Sorakugun, Kyoto 619-0237, Japan, Tel: 81774-98-2716; Fax: 81-774-98-2737; E-mail: nogata7@yahoo.co.jp

Key words: wood creosote, intestine; bacterial flora, minimal inhibitory concentration, ribosomal DNA

Received: February 05, 2018; Accepted: February 21, 2018; Published: February 24, 2018 


\section{Human study}

The study was a single-hospital open trial without a control placebo. Thirty-four healthy adult participants of age $20-50$ years were initially enrolled, from which five males and five female participants eligible for the study were selected. Written informed consent was obtained from each participant. Exclusion criteria were those undergoing treatment with a doctor or dentist, having a fever or diarrhea, pregnant or may be pregnant, allergic to WC, constipated, on medication, or those who had taken other medicines within 7 days of initiating the study. Standard blood chemistry analyses, urine analyses and physical analyses, including an electrocardiogram examination, were performed for each participant just before the commencement of the study, and all the data were confirmed to be normal. The study protocol and consent form were approved by Miyawaki Orthopedic Clinic Clinical Study Ethics Committee (Hokkaido, Japan). The study was registered to University Hospital Medical Information Network (UMIN Clinical Trial Registry; UMIN000026926) before the commencement of the trial.

Feces were collected on day 1, day 2 and day 3 of the study from each participant. WC (capsule medicine, Seirogan Quick C, Taiko Pharmaceutical) was then given orally on day 4 at a dose of 3 capsules (each capsule containing $45 \mathrm{mg}$ WC) within $30 \mathrm{~min}$ after a meal. This dosing was done for each meal (three times a day); a total of 9 capsules were administered to each participant on day 4 . Feces were again collected on day 5 , day 6 and day 7 . When feces could not be obtained on a scheduled day, the collection of feces was done on the following day(s), and the entire study schedule was shifted to later day(s). All feces were stored frozen until analysis. On the day of analysis DNA was extracted from the feces as described previously [14]. Next, the copy number of $16 \mathrm{~S}$ ribosomal DNA (rDNA) of target bacteria was quantified by real-time PCR using SYBR premix Ex Taq II (Takara, Otsu, Japan) and a Rotor-Gene Q machine (Qiagen, Hilden, Germany) for Bifidobacterium longum. In some experiments, digital PCR [15] was employed to quantify the $16 \mathrm{~S}$ rDNA copy number of DNA samples using Taqman Gene Expression Master Mix and a Biomark System (Fluidigm, South San Francisco, CA, USA) for 16S rDNA of Enterococcus faecalis, Bacteroides fragilis and Clostridium perfringens. The copy number of $16 \mathrm{~S}$ rDNA was expressed per gram of feces.

\section{Statistical analysis}

The copy number of $16 \mathrm{~S}$ rDNA of each bacterium was first expressed as a mean and standard deviation of pre-dose three days (day 1, 2 and 3 ) from each subject. Next, mean and standard deviation of post-dose three days (day 5, 6 and 7) was obtained from each participant. Then, the pre-dose and post-dose means were compared for each participant by a paired one-sided Student's $t$-test. The difference was considered significant if $p<0.05$.

\section{Results}

Initially, we attempted to use real-time PCR to quantify the copy numbers of $16 \mathrm{~S}$ rDNA of bacteria in feces. A time course of the change in copy number of $16 \mathrm{~S}$ rDNA of Bifidobacterium longum in feces is shown in Table 1. Although there are some fluctuations in the copy numbers of $16 \mathrm{~S}$ rDNA both in male and female, the difference was not significant ( $p=0.33$ and 0.47 , respectively) when compared before and after the dosing of WC for the two participants. Similar trends were found for other participants (data not shown). Similar results were obtained when investigating other bacteria (data not shown). Next, we compared means of five male participants and five female participants for pre-dose and post-dose copy numbers of rDNA from Bifidobacterium longum (Table 2), Bacteroides fragilis (Table 3),
Clostridium perfringens (Table 4) and Enterococcus faecalis (Table 5). The copy number did not change significantly for all these four bacteria ( $p=0.48,0.36,0.13$ and 0.14 , respectively). Therefore, we concluded that WC given orally at a usual therapeutic dose is ineffective at killing intestinal bacterial flora. We next measured MIC of WC against bacteria of human isolates. As shown in Table 6 and 7, MIC of WC for all the bacteria tested was $>128 \mu \mathrm{g} / \mathrm{ml}$, suggesting it has no significant antibacterial activity.

Table 1. Time course of the copy numbers of $16 \mathrm{~S}$ rDNA of Bifidobacterium longum in the feces of two subjects

\begin{tabular}{|c|c|c|}
\hline Subject name & Experiment day & Copies per gram feces \\
\hline Male 5 & 1 & $9.0 \times 10^{10}$ \\
\hline Male 5 & 2 & $1.5 \times 10^{11}$ \\
\hline Male 5 & 3 & $2.1 \times 10^{11}$ \\
\hline Mean \pm SD (day 1,2,3) & & $1.5 \times 10^{11} \pm 6.0 \times 10^{10}$ \\
\hline Male 5 & 5 & $2.3 \times 10^{11}$ \\
\hline Male 5 & 6 & $6.6 \times 10^{10}$ \\
\hline Male 5 & 7 & $6.2 \times 10^{10}$ \\
\hline Mean \pm SD (day 5,6,7) & & $1.2 \times 10^{11} \pm 9.6 \times 10^{10}$ \\
\hline $\boldsymbol{p}$ value (day 1,2,3 vs 5,6,7) & & 0.33 \\
\hline Female 6 & 1 & $2.2 \times 10^{10}$ \\
\hline Female 6 & 2 & $2.4 \times 10^{10}$ \\
\hline Female 6 & 3 & $4.4 \times 10^{9}$ \\
\hline Mean \pm SD (day 1,2,3) & & $1.7 \times 10^{10} \pm 1.1 \times 10^{10}$ \\
\hline Female 6 & 5 & $1.7 \times 10^{10}$ \\
\hline Female 6 & 6 & $1.1 \times 10^{10}$ \\
\hline Female 6 & 7 & $2.1 \times 10^{10}$ \\
\hline Mean \pm SD (day 5,6,7) & & $1.6 \times 10^{10} \pm 5.0 \times 10^{9}$ \\
\hline $\boldsymbol{p}$ value (day 1,2,3 vs 5,6,7) & & 0.47 \\
\hline & & \\
\hline & & \\
\hline
\end{tabular}

Table 2. Copy numbers of $16 \mathrm{~S}$ rDNA of Bifidobacterium longum per gram of feces.

\begin{tabular}{|c|c|c|}
\hline Subject name & Pre-dose (mean of 3 days) & Post-dose (mean of 3 days) \\
\hline Male 1 & $5.1 \times 10^{10}$ & $3.1 \times 10^{10}$ \\
\hline Male 2 & $3.3 \times 10^{6}$ & $1.1 \times 10^{7}$ \\
\hline Male 3 & $7.3 \times 10^{8}$ & $8.6 \times 10^{8}$ \\
\hline Male 4 & $2.9 \times 10^{10}$ & $3.6 \times 10^{10}$ \\
\hline Male 5 & $1.5 \times 10^{11}$ & $1.2 \times 10^{11}$ \\
\hline Female 6 & $1.7 \times 10^{10}$ & $1.9 \times 10^{10}$ \\
\hline Female 7 & $1.2 \times 10^{11}$ & $1.4 \times 10^{11}$ \\
\hline Female 8 & $6.7 \times 10^{6}$ & $6.4 \times 10^{6}$ \\
\hline Female 9 & $1.9 \times 10^{11}$ & $1.8 \times 10^{11}$ \\
\hline Female 10 & $9.0 \times 10^{9}$ & $4.6 \times 10^{10}$ \\
\hline Mean & $5.6 \times 10^{10}$ & $5.7 \times 10^{10}$ \\
\hline SD & $7.0 \times 10^{10}$ & $6.4 \times 10^{10}$ \\
\hline$p=0.48$ (pre- vs post-dose) & & \\
\hline & & \\
\hline
\end{tabular}

Table 3. Copy numbers of 16S rDNA of Bacteroides fragilis per gram of feces.

\begin{tabular}{|c|c|c|}
\hline Subject name & Pre-dose (mean of 3 days) & Post-dose (mean of 3 days) \\
\hline Male 1 & $3.3 \times 10^{8}$ & $2.8 \times 10^{8}$ \\
\hline Male 2 & $6.1 \times 10^{8}$ & $9.2 \times 10^{9}$ \\
\hline Male 3 & $3.1 \times 10^{10}$ & $7.5 \times 10^{8}$ \\
\hline Male 4 & $1.4 \times 10^{10}$ & $7,2 \times 10^{10}$ \\
\hline Male 5 & $3.4 \times 10^{9}$ & $1.5 \times 10^{9}$ \\
\hline Female 6 & $4.9 \times 10^{8}$ & $5.7 \times 10^{8}$ \\
\hline Female 7 & $1.8 \times 10^{9}$ & $3.0 \times 10^{9}$ \\
\hline Female 8 & $4.4 \times 10^{10}$ & $3.9 \times 10^{10}$ \\
\hline Female 9 & $1.7 \times 10^{9}$ & $8.8 \times 10^{8}$ \\
\hline Female 10 & $6.3 \times 10^{9}$ & $2.7 \times 10^{9}$ \\
\hline Mean & $1.0 \times 10^{10}$ & $1.3 \times 10^{10}$ \\
\hline SD & $1.5 \times 10^{10}$ & $2.4 \times 10^{10}$ \\
\hline$p=0.36$ (pre- vs post-dose) & & \\
\hline
\end{tabular}




\section{Discussion}

We quantitated mean values of the copy numbers of $16 \mathrm{~S}$ rDNA of three-day pre-dose samples of feces and three-day post-dose samples of feces. Based on the relatively short doubling times of bacteria in the human gut (e.g., $60 \mathrm{~min}$ for Staphylococcus aureus (16)), we reasoned that a three-day period was a suitable length of time for measuring the mean copy numbers of $16 \mathrm{~S}$ rDNA in order to estimate numbers of bacteria in the intestine. In fact, as shown in Table 1, the time course of the $16 \mathrm{~S}$ rDNA copy number did not change significantly during

Table 4. Copy numbers of 16S rDNA of Clostridium perfringens per gram of feces.

\begin{tabular}{|c|c|c|}
\hline Subject name & Pre-dose (mean of 3 days) & Post-dose (mean of 3 days) \\
\hline Male 1 & $2.9 \times 10^{10}$ & $8.7 \times 10^{10}$ \\
\hline Male 2 & $3.2 \times 10^{10}$ & $6.6 \times 10^{10}$ \\
\hline Male 3 & $5.0 \times 10^{10}$ & $3.2 \times 10^{10}$ \\
\hline Male 4 & $1.4 \times 10^{10}$ & $4.5 \times 10^{10}$ \\
\hline Male 5 & $1.5 \times 10^{10}$ & $2.5 \times 10^{10}$ \\
\hline Female 6 & $7.3 \times 10^{9}$ & $4.0 \times 10^{10}$ \\
\hline Female 7 & $1.9 \times 10^{10}$ & $1.0 \times 10^{10}$ \\
\hline Female 8 & $4.6 \times 10^{10}$ & $4.9 \times 10^{10}$ \\
\hline Female 9 & $5.0 \times 10^{10}$ & $4.8 \times 10^{10}$ \\
\hline Female 10 & $5.7 \times 10^{10}$ & $2.2 \times 10^{10}$ \\
\hline Mean & $3.2 \times 10^{10}$ & $4.3 \times 10^{10}$ \\
\hline SD & $1.8 \times 10^{10}$ & $2.2 \times 10^{10}$ \\
\hline$p=0.13$ (pre- vs post-dose) & & \\
\hline
\end{tabular}

Table 5. Copy numbers of 16S rDNA of Enterococcus faecalis per gram of feces.

\begin{tabular}{|c|c|c|}
\hline Subject name & Pre-dose (mean of 3 days) & Post-dose (mean of 3 days) \\
\hline Male 1 & $2.7 \times 10^{10}$ & $9.5 \times 10^{10}$ \\
\hline Male 2 & $3.4 \times 10^{10}$ & $5.2 \times 10^{10}$ \\
\hline Male 3 & $4.1 \times 10^{10}$ & $2.6 \times 10^{10}$ \\
\hline Male 4 & $9.5 \times 10^{9}$ & $3.5 \times 10^{10}$ \\
\hline Male 5 & $1.7 \times 10^{10}$ & $3.1 \times 10^{10}$ \\
\hline Female 6 & $6.0 \times 10^{9}$ & $4.4 \times 10^{10}$ \\
\hline Female 7 & $4.6 \times 10^{10}$ & $3.4 \times 10^{10}$ \\
\hline Female 8 & $4.3 \times 10^{10}$ & $5.3 \times 10^{10}$ \\
\hline Female 9 & $5.4 \times 10^{10}$ & $4.7 \times 10^{10}$ \\
\hline Female 10 & $5.6 \times 10^{10}$ & $2.5 \times 10^{10}$ \\
\hline Mean & $3.3 \times 10^{10}$ & $4.4 \times 10^{10}$ \\
\hline SD & $1.8 \times 10^{10}$ & $2.1 \times 10^{10}$ \\
\hline$p=0.14$ (pre- vs post-dose) & & \\
\hline
\end{tabular}

Table 6. Minimal inhibitory concentration (MIC, $\mu \mathrm{g} / \mathrm{ml}$ ) of wood creosote against indigenous bacterial strains.

\begin{tabular}{|c|c|c|c|c|}
\hline $\begin{array}{c}\text { Name of } \\
\text { bacteria }\end{array}$ & Name of strain & $\begin{array}{c}\text { Concentration of } \\
\text { original broth } \\
\text { (cfu/ml) }\end{array}$ & $\begin{array}{c}\text { Dilution } \\
\text { 1-fold }\end{array}$ & $\begin{array}{c}\text { Dilution } \\
100 \text {-fold }\end{array}$ \\
\hline $\begin{array}{c}\text { Bifidobacterium } \\
\text { longum }\end{array}$ & DWC 2285 & $3.6 \times 10^{8}$ & $>128$ & $>128$ \\
\hline $\begin{array}{c}\text { Bifidobacterium } \\
\text { adolescentis }\end{array}$ & DWC 1480 & $4.1 \times 10^{8}$ & $>128$ & $>128$ \\
\hline $\begin{array}{c}\text { Bacteroides } \\
\text { fragilis }\end{array}$ & DWC 0310 & $1.2 \times 10^{9}$ & $>128$ & $>128$ \\
\hline $\begin{array}{c}\text { Bacteroides } \\
\text { distasonis }\end{array}$ & DWC 0308 & $1.7 \times 10^{9}$ & $>128$ & $>128$ \\
\hline $\begin{array}{c}\text { Clostridium } \\
\text { perfringens }\end{array}$ & DWC 2246 & $3.0 \times 10^{8}$ & $>128$ & $>128$ \\
\hline $\begin{array}{c}\text { Clostridium } \\
\text { difficile }\end{array}$ & DWC 2178 & $2.7 \times 10^{8}$ & $>128$ & $>128$ \\
\hline $\begin{array}{c}\text { Enterococcus } \\
\text { faecalis }\end{array}$ & DWC 1706 & $3.4 \times 10^{8}$ & $>128$ & $>128$ \\
\hline $\begin{array}{c}\text { Enterococcus } \\
\text { faecalis }\end{array}$ & DWC 1687 & $3.9 \times 10^{8}$ & & $>128$ \\
\hline
\end{tabular}

Table 7. Minimal inhibitory concentration (MIC, $\mu \mathrm{g} / \mathrm{ml}$ ) of wood creosote against pathological bacterial strains.

\begin{tabular}{|c|c|c|c|c|}
\hline $\begin{array}{c}\text { Name of } \\
\text { bacteria }\end{array}$ & Name of strain & $\begin{array}{c}\text { Concentration of } \\
\text { original broth } \\
\text { (cfu/ml) }\end{array}$ & $\begin{array}{c}\text { Dilution } \\
100 \text {-fold }\end{array}$ & $\begin{array}{c}\text { Dilution } \\
10000 \text {-fold }\end{array}$ \\
\hline $\begin{array}{c}\text { Salmonella } \\
\text { enteritidis }\end{array}$ & DWC 2224 & $6.9 \times 10^{8}$ & $>128$ & $>128$ \\
\hline $\begin{array}{c}\text { Salmonella } \\
\text { virchow }\end{array}$ & DWC 2223 & $8.2 \times 10^{8}$ & $>128$ & $>128$ \\
\hline $\begin{array}{c}\text { Shigella } \\
\text { sonnei }\end{array}$ & DWC 2216 & $3.5 \times 10^{8}$ & $>128$ & $>128$ \\
\hline $\begin{array}{c}\text { Shigella } \\
\text { dysenteriae }\end{array}$ & DWC 2201 & $2.9 \times 10^{8}$ & $>128$ & $>128$ \\
\hline $\begin{array}{c}\text { Campylobacter } \\
\text { jejuni }\end{array}$ & DWC 2030 & $3.7 \times 10^{8}$ & $>128$ & $>128$ \\
\hline $\begin{array}{c}\text { Campylobacter } \\
\text { coli }\end{array}$ & DWC 2032 & $>5.0 \times 10^{8}$ & $>128$ & $>128$ \\
\hline
\end{tabular}

each 3-day period of sampling. Thus, we concluded that the three-day period of fecal sampling before and after the WC dosing is sufficient to estimate the numbers of bacteria in the intestine.

MIC of common antibiotics are of the order of $0.1-10 \mu \mathrm{g} / \mathrm{ml}$ $[17,18]$. The MICs of WC found in bacteria tested in our experiments was greater than $128 \mu \mathrm{g} / \mathrm{ml}$ (Table 6, 7). Furthermore, WC administered orally is immediately absorbed from the upper gastrointestinal tract [12]. This suggests that the concentration of WC administered orally at the ordinary therapeutic dose would not attain a concentration greater than $128 \mu \mathrm{g} / \mathrm{ml}$ in the lower gastrointestinal tract, such as the lower ileum and colon, where most of the intestinal bacterial floras reside. Thus, we speculate that the antidiarrheal effect of WC is not attributable to its putative antimicrobial effect, but due primarily to its effect in suppressing intestinal motility and inhibition of intestinal fluid secretion via the chloride channel [3-8]. Furthermore, the absence of a noticeable antibacterial effect of orally administered WC suggests that it will not disturb the bacterial flora of the human intestine.

\section{Competing interest}

We declare no competing interest.

\section{References}

1. Ogata N, Baba T (1989) Analysis of beechwood creosote by gas chromatography-mass spectrometry and high-performance liquid chromatography. Res Commun Chem Pathol Pharmacol 66: 411-423. [Crossref]

2. Ogata N, Baba T, Shibata T (1993) Demonstration of antidiarrheal and antimotility effects of wood creosote. Pharmacology 46: 173-180. [Crossref]

3. Ataka K, Ogata N, Kuge T, Shibata T (1996) Suppression of enterotoxin-induced intestinal fluid secretion by wood creosote. Res Commun Mol Pathol Pharmacol 93: 219-224. [Crossref]

4. Ogata N, Shibata $\mathrm{T}$ (2004) Inhibition of rat intestinal Cl-secretion by 4,5-dimethylresorcinol. Pharmacology 72: 247-253. [Crossref]

5. Greenwood-Van Meerveld B, Tyler KR, Venkova K, Kuge T (2000) Comparison of the antidiarrheal effects of wood creosote and loperamide in the rat jejunum and colon in vitro. Biol Pharm Bull 23: 952-956. [Crossref]

6. Ogata N, Ataka K, Morino H, Shibata T (1999) Effect of wood creosote and loperamide on propulsive motility of mouse colon and small intestine. Pharmacology 59: 212-220. [Crossref]

7. Ogata N, Toyoda M, Shibata T (1992) Suppression of intestinal smooth muscle contraction by phenolic compounds. Res Commun Chem Pathol Pharmacol 77: 359366. [Crossref]

8. Toyoda M, Ogata N, Shibata T (1993) Suppression of intestinal smooth muscle contraction by 4-ethylguaiacol, a constituent of wood creosote. Pharmacology 47: 300308. [Crossref]

9. Morino H, Ataka K, Ito M, Kuge T (2004) Wood creosote inhibits calcium mobilization in Guinea pig colonic smooth muscle. Biol Pharm Bull 27: 1046-1051. [Crossref] 
10. Ataka K, Kuge T, Fujino K, Takahashi T, Fujimiya M (2007) Wood creosote prevents CRF-induced motility via 5-HT3 receptors in proximal and 5-HT4 receptors in distal colon in rats. Auton Neurosci 133: 136-145. [Crossref]

11. Baba T, Nishino T, Tani T (2003) Effects of herbal drugs prescribed in wood creosote pills on the dissolution profile of guaiacol. Biol Pharm Bull 26: 194-198. [Crossref]

12. Ogata N, Matsushima N, Shibata T (1995) Pharmacokinetics of wood creosote: glucuronic acid and sulfate conjugation of phenolic compounds. Pharmacology 51:195-204. [Crossref]

13. A guide to sensitivity testing (1991) Report of the working party on antibiotic sensitivity testing of the British Society for Antimicrobial Chemotherapy . J Antimicrob Chemother 27: SuppleD 1-50. [Crossref]

14. Takahashi S, Tomita J, Nishioka K, Hisada T, Nishijima M (2014) Development of a prokaryotic universal primer for simultaneous analysis of Bacteria and Archaea using next-generation sequencing. PloS ONE 9: e105592. [Crossref]
15. Morley AA (2014) Digital PCR: A brief history. Biomol Detect Quantif 1: 1-2. [Crossref]

16. Domingue G, Costerton JW, Brown MR (1996) Bacterial doubling time modulates the effects of opsonisation and available iron upon interactions between Staphylococcus aureus and human neutrophils. FEMS Immunol Med Microbiol 16:223-228. [Crossref]

17. Flórez AB, Mayo B (2017) Antibiotic resistance-susceptibility profiles of Streptococcus thermophilus isolated from raw milk and genome analysis of the genetic basis of acquired resistances. Front Microbiol 8: 2608. [Crossref]

18. Khanal PR, Satyal D, Bhetwal A, Maharjan A, Shakya S, et al. (2017) Renaissance of conventional first-line antibiotics in Salmonella enterica clinical isolates: assessment of MICs for therapeutic antimicrobials in enteric fever cases from Nepal. Biomed Res Int 2017: 2868143. [Crossref]

Copyright: $\odot 2018$ Ogata N. This is an open-access article distributed under the terms of the Creative Commons Attribution License, which permits unrestricted use, distribution, and reproduction in any medium, provided the original author and source are credited. 